\title{
Analysis of Cooperation between Science and Business in the Function of Improving the Effectiveness of the Republic of Serbia Economic Growth
}

\author{
Ivan Stošić $^{*}$ ｜ Duško Bodroža ${ }^{1}$ | Mihajlo Đukić ${ }^{1}$ \\ ${ }^{1}$ Institute of Economic Sciences, Belgrade, Serbia
}

\begin{abstract}
The subject of this paper is the analysis of cooperation between science and business in the Republic of Serbia. The main goal of the paper is to identify the level of cooperation, the achieved results and the scientific areas in which the cooperation is being carried out, through the analysis of the current state of cooperation between science and business. The paper should serve as the starting point for future research, where the effects of profitability of investments in science at macro and micro level will be evaluated. The analysis used the official data on the achieved results in scientific research activities from the Statistical Office of the Republic of Serbia, and data from the Ministry of Education, Science and Technological Development. The obtained results showed that Serbia has a potential in the science sector, but that it is not sufficiently used by the economy since researchers focus exclusively on the production of scientific work.
\end{abstract}

Key words: science, economy, business, cooperation, results, Republic of Serbia

JEL Classification: 030, 032, I25

\section{INTRODUCTION}

Topicality for making this paper immerges from ascertainment that cooperation between science and business in the Republic of Serbia is still dissatisfactory. Until now, an efficient way of linking science and economy has not functioned, neither to ensure the mobilisation and capitalisation of knowledge and research, nor their coordination. Economy does not use the results of scientific research sufficiently and does not encourage the development of research, which may have many benefits over a longer time horizon. On the other hand, the scientific community, due to the decades-long absence of a market economy, often has no proactive approach in the context of promoting the results of its research to business entities, thus ensuring their practical application as well as verification of theoretical concepts.

According to "The Strategy of Scientific and Technological Development of the Republic of Serbia for the Period from 2016 to 2020 - Research for Innovation" ("Official Gazette of RS", No. 55/05, 71/05 - correction, 101/07, 65/08, 16 / 11, 68/12 - US, 72 / 12,7 / 14 - US and 44/14), the current relationship of science and economy in the Republic of Serbia is characterized by insufficient level of human resources, a small number of financial instruments, and the insufficiently developed institutional and legal framework for supporting research and innovation in the economy. In order for this cooperation to be successful, stronger links between

\footnotetext{
* Corresponding author, e-mail: ivan.stosic@ien.bg.ac.rs
} 
the educational and research system with the economy are needed in order to more efficiently utilise existing resources, as well as those which are created through higher education and research.

The aim of this analysis is to determine the current state of cooperation between science and economy and identify the scientific areas and sectors where cooperation exists. The obtained results will be used as a starting point in future research, in which, using the worldly recognised methodology, the effects of an investment in science at macro and micro level will be measured.

The paper consists of three parts. In the first part, we provide an overview of the basic forms of cooperation between science and business, as well as a review of relevant scientific literature in which the relationship between science and economy was analyzed. The second part is devoted to the analysis of the capacities of research and development organisations in the Republic of Serbia, their achieved results, and financial resources spent on research and development. In the third part, as part of the concluding observations, we indicate the main sectors in which cooperation between science and economy is being realized, as well as problems that make the successful realisation of this cooperation difficult.

\section{COOPERATION OF SCIENCE AND BUSINESS - GENERAL INFORMATION}

The most important resource that a society has at its disposal is knowledge. Unlike other resources, such as natural (mineral and water resources, arable land, etc.), knowledge as a resource cannot be stored freely (Babić, 2013), but it must always be renewed and always reacquired otherwise it will disappear and perish. This renewal can be achieved by transferring knowledge, education and extending the scope of existing knowledge through research, which we call science (Babić, 2013). In order to achieve this continuous renewal of knowledge, significant material resources, both in education and in science, are invested in the world.

Modern society requires a high level of knowledge and transfer of this knowledge into new products, processes and services. Science, technological development and innovation play an important role in fostering economic development and are a key factor in competitiveness and sustainable development. In order to respond adequately to the rapid economic advancement of society, a stronger link between science and the economy is needed. Cooperation of science and economy is realized in two directions: the science on precise requirements of the business corresponds to solve important problems and science offers the business something new, improved or more accessible

In order for this cooperation to be successful, in addition to the necessary knowledge and competencies of science, it is very important that the economy recognises the importance of science in modern business conditions. According to the European Commission report "The state of the European university-business cooperation" (EK, 2011) a total of eight forms of two-way cooperation between science and business are distinguished: 


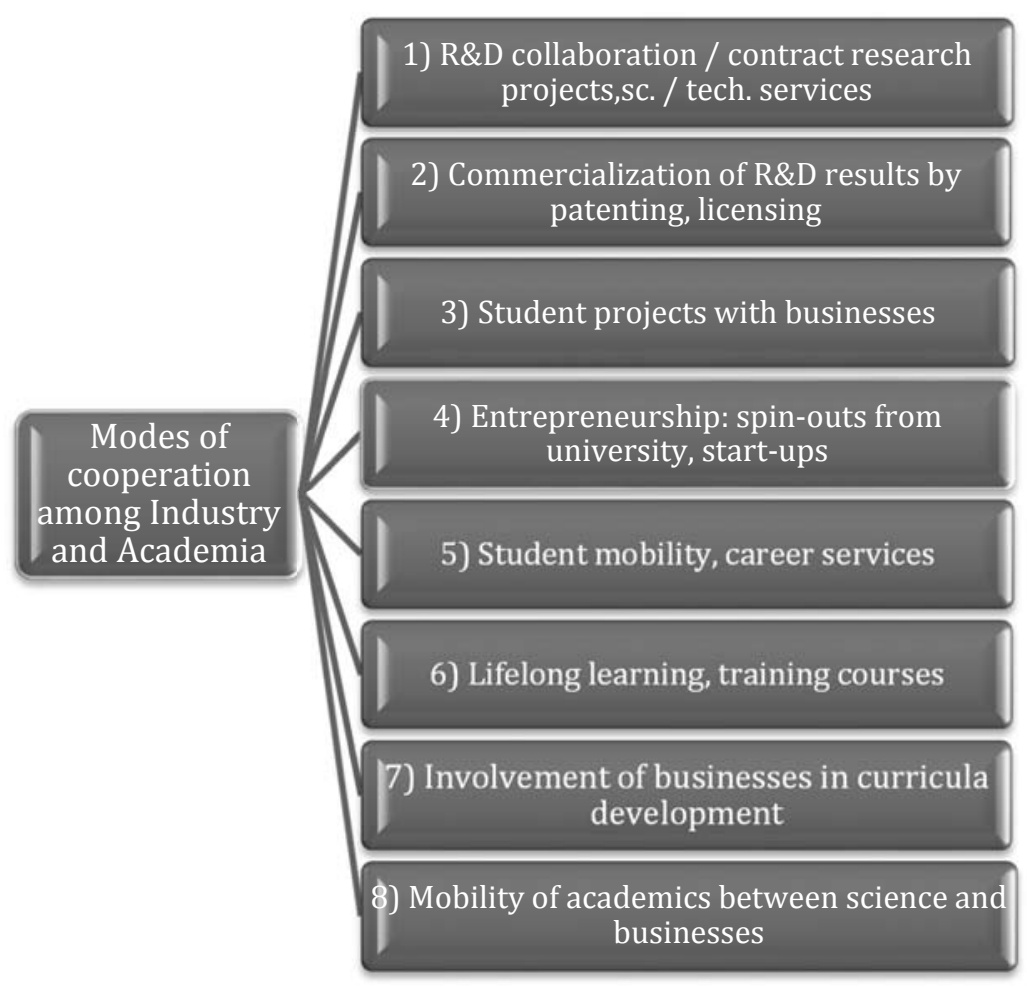

Graph 1. Forms of cooperation between science and business

Source: The European Commission

The most popular form of cooperation is in the field of $\mathrm{R} \& \mathrm{D}$, and it covers a whole range of joint research and development activities, research projects contracts, joint publications of scientists/researchers with business entities employees, as well as joint mentorship in a master and doctoral thesis. Another aspect of cooperation is the commercialisation of research and development results that requires establishing of support mechanisms and relevant legislation

The following very important form of cooperation relates to cooperation between students and the economy. Students perform joint projects and practice in companies, which in this way mobilise high-quality staff. New developments in the market create a growing need for innovative culture and entrepreneurial behaviour, and it is very important that as a result of cooperation between science and economy, new spin-off and start-up companies will be established. The pressure of competition in all markets, including the labour market, imposes continuous education and acquisition of new knowledge and skills that meet the needs of present society. For this reason, Lifelong Learning Programs provide skills and knowledge to employees and their managers in order to adapt to the demands of modern society. The flexibility of the labour market is important in the process of absorption of future graduates, so it is recommended that the representatives of the business participate in the creation of study programs. The last form of science and business cooperation is academic mobility with the economy. Managers are members of the board of directors at faculties and institutes, while on the other hand, academic and scientific workers are involved in decision-making in companies

For the successful cooperation between science and economy, the following factors are important (Rakovska N. et al, 2012):

- Common goals - cooperation should be based on mutual benefits, needs and goals,

- Commitment - A good partnership is in the hands of "right people", starting with leadership and involving all organisational levels, 
- Communication - establishing a current and open dialogue, mutual trust and good knowledge is an important factor for successful cooperation. Career centres and specialised departments, such as industry liaison departments, technology transfer centres, technology parks, business incubators, etc., have a special role in linking science and the economy, and

- Context - Scientific and business cooperation should be considered as a priority and has to be supported by adequate legislation. In addition, it is necessary to provide financial support to the national and institutional levels.

There is a large number of authors who have confirmed the importance of investments in research and development in order to strengthen the competitive position of individual economic entities and, consequently, the economy as a whole. In doing so, it is of particular importance that the synergetic effect is achieved by the state incentives for businesses to treat the research as one of the priority factors of long-term development. In this regard, investments in research and development are considered as an investment rather than cost and are especially important in periods of recession when it is necessary to encourage the investment cycle, provide the basis for future growth and stimulate aggregate demand. In such situations, companies often hesitate or postpone this type of investment, which may have negative consequences for the entire economy.

Brautzsch et al. (2015) analysed the incentive program that Germany created in the aftermath of the global crisis in 2009 to encourage research and development and investment in equipment. Compared to the initial budget of $€ 626$ million, Germany provided an additional $€$ 900 million from the budget to finance research and development activities of small and medium-sized enterprises (up to 1000 employees). In their research, the authors confirmed the justification of investments both in the production phase and in the stage of consumption of the earned income, stating that the value of the multiplier of output, added value and employment was around 2. Thanks to the initiated investment cycle, the total value of production increased by almost 900 million euros, ie there was an increase of added value by over 360 million euros and over 7000 newly created jobs. Certainly, a large number of authors point to the needs of a detailed analysis of the best modalities of cooperation between the state and the economy and how the state, by stimulating research at the company level, achieves the best effects, both at the level of the economy as a whole, and at the level of the companies. In this regard, it is necessary to pay particular attention to possible crowding out and measurement of the effects of various incentives - financing of researches through specially developed programs and tax incentives.

Guellec and De La Potterie (2003) state that the funding of research and development programs and tax incentives significantly stimulate private sector investments and in that sense have positive effects on the development of the economy. On the other hand, state researches lead to crowding out, while researches at the level of higher education institutions have neutral effects on business investments. The government's investment effects are in the form of a Ucurve, with the largest effects reaching a $10 \%$ increase over the initial level of investment. An increase of more than $20 \%$ is a substitute for private sector investments. Bearing in mind that the analysis encompassed 17 OECD countries in the period 1981-1996, it should be noted that the effects in a particular country must take into account both the specificities of economic conditions and the local context, the current level of investment in $\mathrm{R} \& \mathrm{D}$, as well as the level of economic development in certain sectors and in total. Nevertheless, Guellec and De La Potterie point out that in any context, stable versus volatile and unpredictable investment policy yields better results and that incentive instruments have the character of substitutability, which means that increased use of one reduces the effectiveness of another instrument.

Petrović (2013) states that science is an important factor in the recovery of the industry and that a small country can also develop high technology. World experiences show those countries which have continuously invested in research and education more successful and resilient to the crisis. Hodžić (2011) notes that the nature of science and technology is such that at a time when 
the cost of S\&T occurs is impossible to measure future economic benefits. Then one can only assume that the long-term economic benefits are just the result of research and development costs. However, according to the results presented by Zubović et. al (2013), we may conclude that the Republic of Serbia should use its research and development capabilities in order to achieve a competitive position in the global market based on knowledge and innovation.

Monitoring the international position of countries in science and innovation has been a challenge for governments, their specialised bodies, international organisations and institutions for decades. The reason for this is found in the fact that the economic development of the country is directly influenced by the development of science and technology, that is, research and innovation activities.

Numerous domestic authors have dealt with various issues of improving the effectiveness and efficiency of science in Serbia - Rašević et. al (2013), Kutlača et. al (2016), Šipka (2016) In all these works, it is common to point out that science and innovation are considered as key factors of competitiveness and sustainable development, especially knowledge-based development. On the other hand, in all these works, there is a common indication of the numerous problems that burden the science in Serbia, where insufficient cooperation between science and economy is found as the most prominent one.

\section{COOPERATION BETWEEN SCIENCE AND BUSINESS IN THE REPUBLIC OF SERBIA}

Researches in Serbia are exclusively concentrated in the public sector at universities and institutes. According to the data of the Statistical Office of the Republic of Serbia, a total of 280 organisations are engaged in research and development, out of which 111 are higher education institutions, 107 come from the non-financial sector, 54 from the state sector and 8 from the non-profit sector. Observed by scientific fields, the largest number of organisations are engaged in research and development in the field of engineering and technology and social sciences, a total of 103 and 62 organisations respectively.

Table 1. R \& D organisations by sectors and scientific fields, 2017

\begin{tabular}{|c|c|c|c|c|c|}
\hline & Total & $\begin{array}{c}\text { Non-financial } \\
\text { sector }\end{array}$ & State sector & $\begin{array}{c}\text { Higher } \\
\text { education }\end{array}$ & $\begin{array}{c}\text { Non-profit } \\
\text { sector }\end{array}$ \\
\hline Republic of Serbia & 280 & 107 & 54 & 111 & 8 \\
\hline - Natural Sciences & 47 & 19 & 11 & 16 & 1 \\
\hline - Engineering and technology & 103 & 68 & 9 & 23 & 3 \\
\hline - Medical and health sciences & 19 & 9 & 3 & 7 & - \\
\hline - Agricultural sciences & 26 & 9 & 11 & 6 & - \\
\hline - Social sciences & 62 & 2 & 9 & 47 & 4 \\
\hline - Humanities & 23 & - & 11 & 12 & - \\
\hline
\end{tabular}

Source: Statistical Office of the Republic of Serbia

In R \& D organisations, 22,782 persons are employed in total, out of which the majority are researchers - 16,182. Of the remaining number of employees, technical staff is 3,037, professional associates 1,533, management staff 559 persons and other staff 1,471 persons. The largest number of persons are employed in technical $(6,729)$ and natural sciences $(5,185$ persons). Social sciences employ a total of 3,765 persons, medical sciences and health sciences 2,804 persons, while in agricultural and humanistic sciences there are a total of 2,458 or 1,841 employees. 
Table 2. Full-time and part-time employees on research and development activities, by sectors, science fields and gender, 2017 (number of persons)

\begin{tabular}{|c|c|c|c|c|c|c|c|c|c|c|c|c|}
\hline \multirow{3}{*}{\begin{tabular}{|l} 
\\
Republic of Serbia
\end{tabular}} & \multicolumn{2}{|c|}{ Total } & \multicolumn{2}{|c|}{ Researches } & \multicolumn{2}{|c|}{\begin{tabular}{|c|} 
Professional \\
Associates \\
\end{tabular}} & \multicolumn{2}{|c|}{$\begin{array}{c}\text { Technical } \\
\text { staff }\end{array}$} & \multicolumn{2}{|c|}{ Management } & \multicolumn{2}{|c|}{ Other staff } \\
\hline & total & female & total & female & total & male & total $\mathrm{f}$ & emale & total & rale & $\mathbf{t}$ & na \\
\hline & 22,782 & 11,411 & 16,182 & 8,098 & 1,533 & 778 & 3,037 & 1,539 & 559 & 214 & 1,471 & 782 \\
\hline - Natural Sciences & 5,185 & 2,631 & 3,977 & 2,062 & 299 & 130 & 590 & 287 & 96 & 34 & 223 & 119 \\
\hline - Engineering and technology & 6,729 & 2,649 & 4,352 & 1,704 & 603 & 236 & 1,138 & 434 & 226 & 63 & 410 & 212 \\
\hline - Medical and health sciences & 2,804 & 1,715 & 2,419 & 1,454 & 75 & 55 & 143 & 94 & 59 & 41 & 108 & 71 \\
\hline - Agricultural sciences & 2,458 & 1,235 & 1,134 & 568 & 191 & 118 & 531 & 287 & 65 & 23 & 537 & 239 \\
\hline - Social sciences & 3,765 & 2,072 & 2,848 & 1,480 & 194 & 121 & 481 & 320 & 91 & 43 & 151 & 108 \\
\hline Humanities & 1,841 & 1,109 & 1,452 & 830 & 171 & 118 & 154 & 117 & 22 & 10 & 42 & 3 \\
\hline
\end{tabular}

Source: Statistical Office of the Republic of Serbia

In the past few years, Serbia has improved its scientific research potential and, according to SCImago Journal \& Country Rank, Serbia participated in $0.15 \%$ of the total worldwide scientific work and ranked $54^{\text {th }}$ in the list of 239 countries in total. The total number of realised research projects and studies in 2017 was 10,093. Of this, the largest number of research works are fundamental - 4,694, there is 3,705 applied works, and 1,694 development works. Observed by sectors, the largest number of research works were carried out in higher education institutions, that is 6,215 works. The state sector accomplished 2,678, the non-financial sector 1,174 and the non-profit sector 26 research projects and studies.

The total value of all realised research projects and studies is 41,531 million RSD, out of which the research works were worth 15,521 million RSD, development 13,638 million RSD and fundamental 12,371 million RSD.

Table 3. Research works (projects and studies) by sectors, 2017

\begin{tabular}{|c|c|c|c|c|c|c|c|c|}
\hline & \multicolumn{4}{|c|}{ Number of scientific works } & \multicolumn{4}{|c|}{ Value of scientific works, 000 RSD } \\
\hline & Total & Fundamental $A$ & ppliedD & pment & Total & Fundamental & Applied & Development \\
\hline Republic of Serbia & 10,093 & 4,694 & 3,705 & 1,694 & $41,531,049$ & $12,371,06$ & $15,521,581$ & $13,638,401$ \\
\hline $\begin{array}{l}\text { - Non-financial } \\
\text { sector } \\
\end{array}$ & 1,174 & 195 & 468 & 511 & $15,230,986$ & 342,908 & $7,079,232$ & $7,808,846$ \\
\hline - State sector & 2,678 & 1,389 & 881 & $40 \AA$ & $11,228,148$ & $5,117,088$ & $3,380,352$ & $2,730,708$ \\
\hline - Higher education & 6,215 & 3,089 & 2,351 & 775 & $15,040,402$ & $6,908,199$ & $5,033,356$ & $3,098,847$ \\
\hline - Non-profit sector & $2 €$ & 21 & 5 & & 31,513 & 2,872 & 28,641 & \\
\hline
\end{tabular}

Source: Statistical Office of the Republic of Serbia

The largest number of research projects and studies is from technical and social sciences, a total of 3,537 or 2,687 works. It should be kept in mind that in social sciences, most research works were involved in fundamental research $(2,018)$, while applied and development researches included 554 and 106 works. The table below gives an overview of the number and value of research works by scientific areas. 
Table 4. Research works (projects and studies) by scientific areas, 2017

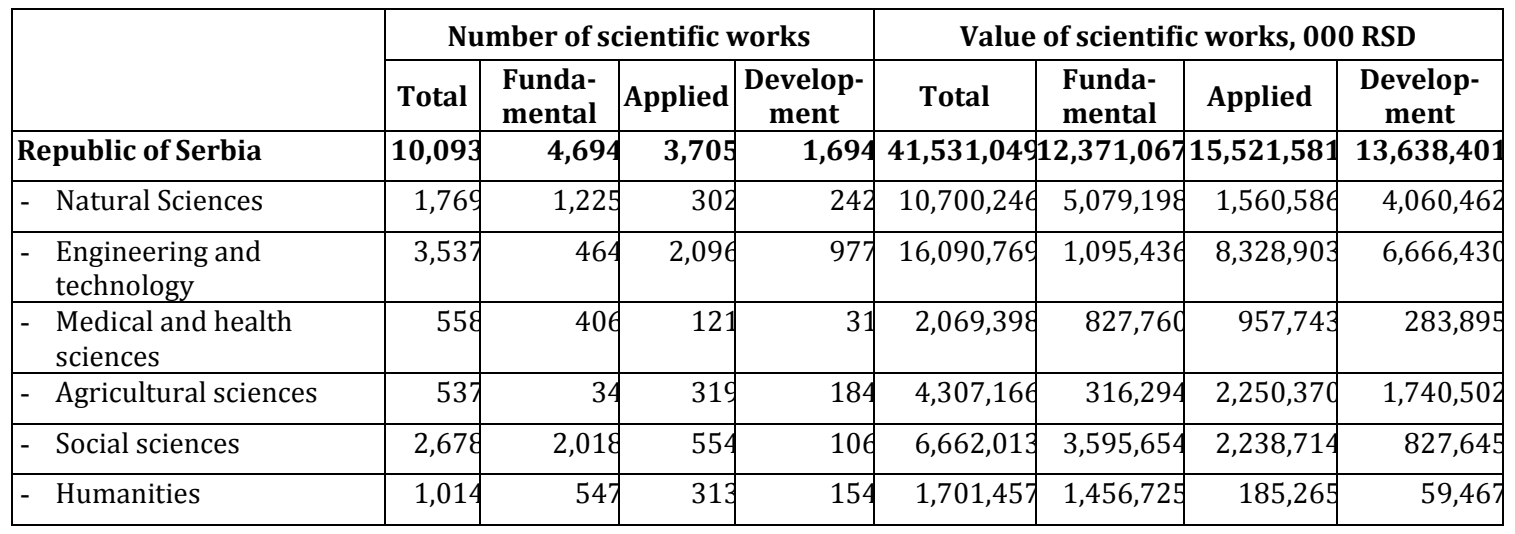

Source: Statistical Office of the Republic of Serbia

In 2017, out of the total number of research and development works, in 6,139 cases, the contracting parties were ministries, while the economy commissioned only 773 researches. The largest number of ordered researches in business is in technical, and natural sciences, 621 or 94 $\mathrm{R} \& \mathrm{D}$ works, and in most cases they were engaged in applied and developmental research.

Table 5. Research and Development works by Contracting party, scientific areas and type of research, 2017

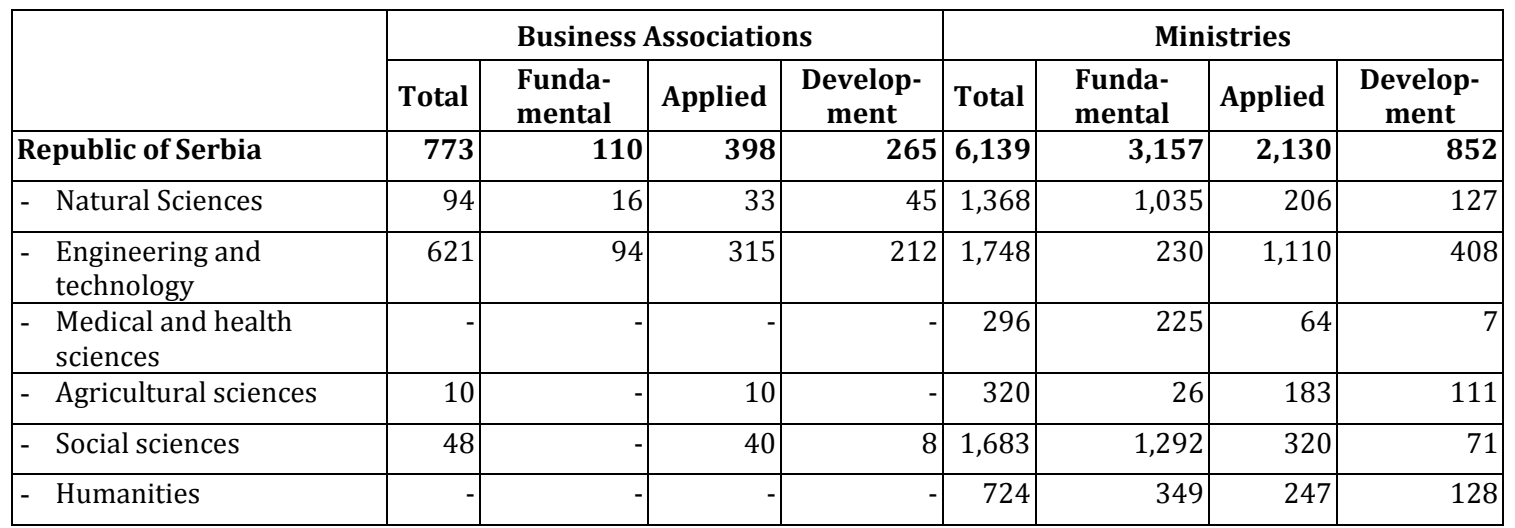

Source: Statistical Office of the Republic of Serbia

Compared to developed countries, investment in science in Serbia is considerably more modest. According to the Statistical Office of the Republic of Serbia, the share of total budget funds for research and development in 2017 amounted $0.40 \%$ of GDP. According to Eurostat data in the EU28 countries, the total allocation for research and development participates with $2.06 \%$ of GDP.

The largest amount of funds spent for research and development activities in 2017 was in technical and natural sciences that participated with $38.7 \%$ and $25.8 \%$ respectively in the total sources of funding for R \& D activities. Of the other sciences, social and agricultural sciences participate with $16.0 \%$ and $10.4 \%$ respectively, while the participation of medical and humanistic sciences is $5.1 \%$ and $4.1 \%$ respectively in the total sources of funding for research and development activities. 
Table 6. Sources of funds spent on research and development activities, 2017 in 000 RSD

\begin{tabular}{|c|c|c|c|c|c|c|}
\hline & Total & $\begin{array}{l}\text { Own } \\
\text { funds }\end{array}$ & $\begin{array}{l}\text { State and local } \\
\text { government }\end{array}$ & $\begin{array}{c}\text { Private and } \\
\text { public } \\
\text { companies }\end{array}$ & $\begin{array}{c}\text { Non-profit } \\
\text { institutions }\end{array}$ & $\begin{array}{l}\text { Foreign } \\
\text { investors }\end{array}$ \\
\hline Republic of Serbia & $41,531,049$ & $9,751,556$ & $19,334,739$ & $4,173,842$ & 2,345 & $8,268,567$ \\
\hline - Natural Sciences & $10,700,246$ & $1,221,219$ & $5,502,870$ & 790,072 & 545 & $3,185,540$ \\
\hline 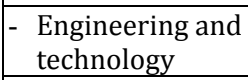 & $16,090,769$ & $3,206,739$ & $6,094,963$ & $3,184,316$ & & $3,604,751$ \\
\hline \begin{tabular}{|l} 
- $\begin{array}{l}\text { Medical and } \\
\text { health sciences }\end{array}$ \\
\end{tabular} & $2,069,399$ & 124,533 & 912,314 & & & $1,032,551$ \\
\hline \begin{tabular}{|l|} 
- Agricultural \\
sciences
\end{tabular} & $4,307,166$ & $2,266,369$ & $1,552,936$ & 155,433 & & 332,428 \\
\hline - Social sciences & $6,662,013$ & $2,594,973$ & $3,942,323$ & 44,021 & 1,800 & 78,896 \\
\hline Humanities & $1,701,457$ & 337,723 & $1,329,333$ & & & 34,401 \\
\hline
\end{tabular}

Source: Statistical Office of the Republic of Serbia

According to the Statistical Office of the Republic of Serbia data, the highest amount of funds for research and development activities is allocated by the state and its authorities, which is RSD 19,335 million in 2017. The system of financing from budget funds includes a total of 16 programs of general interest which are financed by the project after publicly conducted calls and selection according to predetermined criteria. The largest part of funds (68.4\%) is intended for financing scientific projects that were accepted at the competition announced in 2011. Of the $68.4 \%$ of funds, $56.9 \%$ goes to the costs of the work of the researchers, $8.3 \%$ to the overheads of the institution in which the survey is conducted, and the remaining $3.2 \%$ is for the material costs of the projects. These percentages clearly show the difficult position of science in Serbia. Low R\&D budget influences the quality and scope of research. Since a relatively large amount of funds is spent on salaries, there is a small amount of disposable budget which could be allocated for the purchase of the research material and core research activities (MPNTR, 2017).

In addition to the state funding, research and development activities are still financed from own funds (RSD 9,752 million) and foreign investors (RSD 4,173 million). Private and public companies account for 4.174 million RSD, which is only $10.0 \%$ of the total funds spent on this purpose.

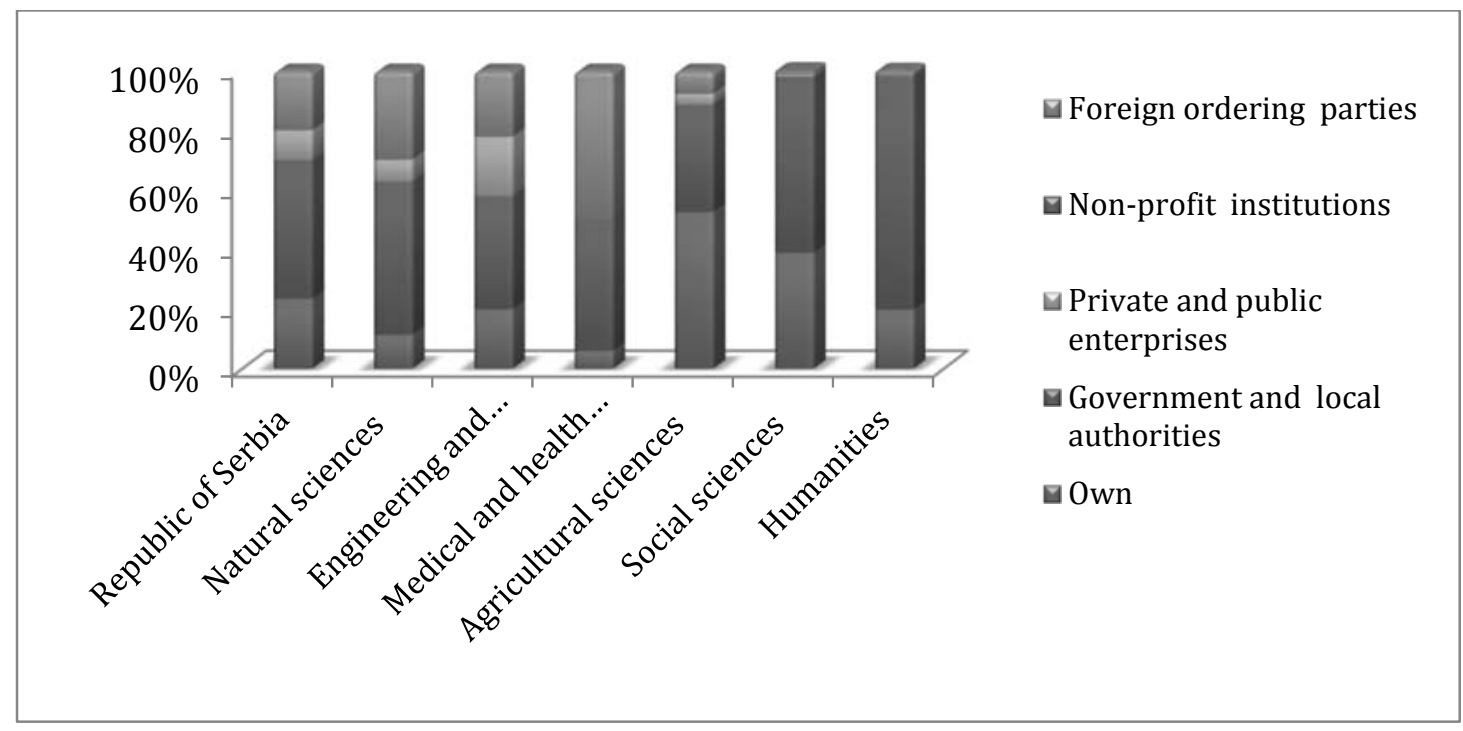

Graph 2. Sources of funds spent on R\&D activities, 2017

Source: Statistical Office of the Republic of Serbia 
If we observe $\mathrm{R} \& \mathrm{D}$ expenditures according to the activity, the largest percentage of spent funds is in scientific research and development $45.7 \%$, education $36.2 \%$ and other mining and quarrying 5.2\%. These three groups of activities together account for $87.1 \%$ of total research and development expenditure.

Table 7. Gross domestic expenditure on R \& D in grouped activities, 2017

\begin{tabular}{|l|r|}
\hline & Gross domestic expenditure \\
\hline Republic of Serbia & $\mathbf{4 1 5 3 1 0 4 9}$ \\
\hline - Scientific R \& D & $45.7 \%$ \\
\hline - Education & $36.2 \%$ \\
\hline - Other mining and quarrying & $5.2 \%$ \\
\hline - Veterinarian activities & $3.0 \%$ \\
\hline - Electricity, gas, steam and air conditioning supply & $2.4 \%$ \\
\hline - Service activities in mining and geological exploration & $2.3 \%$ \\
\hline - Other activities & $5.2 \%$ \\
\hline
\end{tabular}

Source: Statistical Office of the Republic of Serbia

\section{CONCLUSIONS}

The analysis of the presented results clearly shows that Serbia has significant potential in the science and research sector that the economy is not sufficiently utilising. The problem also originates from the fact that a large part of the domestic economy is privatized, and the largest number of $\mathrm{R} \& \mathrm{D}$ departments of these companies is abroad in countries of the parent companies. In addition, due to the high costs of research and development, the domestic economy relies more on the purchase of license-solutions from abroad than on its own development, as evidenced by the fact that the very small percentage of researchers in Serbia is engaged in the private sector

The highest institutional and personnel capacities for cooperation between science and economy currently have technical and natural sciences in which the highest number of research projects and studies are implemented at higher education institutions. Unfortunately, the big issue arises from the fact that published works, except in technical sciences, have a fundamental character that is not applicable in the short term. In addition, the domestic education system is much lagging behind and is not in line with the needs of the domestic and global markets.

Research activities are focused exclusively on the production of scientific papers. The main contractors of research projects and studies are the Ministries, while the economy in the total of ordered R \& D projects and studies participates with only $11.2 \%$. Funds from the budget and own funds continue to be the main source of science funding, while private and public enterprises in the financing of science account for only $10.0 \%$. The level of monetary investments in scientific and technological research and scientific infrastructure in the Republic of Serbia has been stable over the past five years, but in comparison with the countries of the region and especially the world, it is insufficient to provide technological development of the country.

However, presented results clearly show that Serbia has potential in the science and research sector, but that this potential is not being transferred to new products and services on the market. Inside the research system, no appropriate steering mechanisms necessary to ensure that the results of the research find their way to a competitive product or service have been established.

In addition to the aforementioned challenges, representatives of the scientific community, as the main obstacles to cooperation between science and economy, see the lack of financial resources and their incompatibility, as well as an insufficient number of prospective projects. On the other hand, the representatives of the business, as the main issues, indicate too high 
research and development costs, mismatching the duration of scientific projects with the needs of the economic cycle, inefficient system of transfer of scientific knowledge and technologies, as well as inadequate state support. All this points to the numerous challenges that stand as an obstacle to the greater role of science in the function of improving the effectiveness of the economic growth of the Republic of Serbia, which should be overcome in the coming period.

\section{REFERENCES}

Babić, J. (2013). Uloga i značaj nauke i znanja sa posebnim osvrtom na društvene nauke, Istraživanje u oblasti društvenih nauka u Srbiji: Pregled stanja, karakteristični problemi i preporuke, Regional research, Promotion programme Western Balkans, Beograd.

Brautzsch, H. U., Günther, J., Loose, B., Ludwig, U., \& Nulsch, N. (2015). Can R\&D subsidies counteract the economic crisis?-Macroeconomic effects in Germany. Research Policy, 44(3), pp. 623-633.

European Commision. (2011). The state of the European university-business cooperation

European Commission, Smart specialization platform (SSP). Http://s3platform.jrc.ec.europa.eu/eye-ris3.

Eurostat, https://ec.europa.eu/eurostat/web/science-technology-innovation/data/maintables.

Guellec, D., \& Van Pottelsberghe De La Potterie, B. (2003). The impact of public R\&D expenditure on business R\&D. Economics of innovation and new technology, 12(3), pp. 225243.

Hodžić, S. (2011). Stimulacija poreznih olakšica za istraživanje i razvoj, working paper, Institute for Public Finance, Zagreb, Croatia.

Kutlača, Đ., Semenčenko, D. \& Nedović, V. (2016). Smart specialization in Serbia - Challenges for governance of research and innovation, 23th scientific conference Technology, culture and development, proceedings, Tivat, Montenegro, Association "Technology and culture", ISBN 978-86-915151-3-7, COBISS.SR-ID 230384908, pp. 7-21.

OECD. (2010). Science, technology and innovation indicators for policymaking in developing countries: an overview of experiences and lessons learned, http://innovacion.ricyt.org/files/UNCTAD.pdf.

OECD. (2015). Science, Technology and Industry Scoreboard, Innovation for growth and society, http://www.oecd-ilibrary.org/science-and-technology/oecd-science-technologyandindustry-scoreboard-2015_sti_scoreboard-2015-en(http://www.oecdilibrary. Org/docserver/download/9215031e.pdf?Expires=1479640759\&id=id\&accname=guest\&chec ksum=F5C140B89980CADEFBA6BC25FE649D5A) (19.11.2016.)

OECD. EC. Oslo Manual, (2005). The Measurement of Scientific and Technological Activities, Paris, Third edition, OECD, EC.

Petrović, P. (2013). Zemlje koje ulažu u nauku otpornije su na krizu, available on:www.vibilia.rs/srpski/izvestaj/0508/Zemlje\%20koje\%20ulazu.pdf

Rakovska N., Pavlin S. \& Melink M. (2012). Assessment of cooperation between higher education institutions and employers in Europe, EMCOUS and Europen Commision - Lifelong learning programme

Rašević, M., Pavlov, T. \& Stanković, D. (2013). Ka unapređenju saradnje između naučne zajednice i kreatora politika u Srbiji, u Stošić, I., Radovanović, B. I Đukić, M. (ur.): Istraživanja u oblasti društvenih nauka u Srbiji: Pregled stanja, karakteristični problemi i preporuke, Beograd: Institut ekonomskih nauka, pp. 135-146.

Statistical Office of the Republic of Serbia, Scientific research activity, 2017.

Science and Engineering Indicators (2016). National Science Board, https://www.nsf.gov/statistics/2016/nsb20161/uploads/1/nsb20161.pdf

Scimago Journal \& Country Rank, https://www.scimagojr.com/countryrank.php 